\title{
SMALL AND MEDIUM-SIZED ENTERPRISES IN TOURISM AND THEIR IMPACT ON REGIONAL DEVELOPMENT
}

\author{
Katarína Král'ová ${ }^{1}$ \\ Jana Sochul'áková ${ }^{2}$ \\ Dagmar Petrušová ${ }^{3}$
}

DOI: https://doi.org/10.31410/ITEMA.2020.47

\begin{abstract}
A long-term problem of the Slovak economy is significant regional disparities caused by insufficient use of existing local resources. Inefficient and unsystematic use of existing resources at the local level causes a decrease in the competitiveness of these regions, which is also reflected in the overall performance of the economy. In our article, after the initial definition of basic terminology, we will focus on the evaluation of regional disparities and the current development of regional differences in the conditions of the Slovak Republic. We will evaluate the impact of SMEs on regional development in the Slovak Republic. However, we will focus primarily on their positive benefits to reducing regional disparities in the conditions of the Slovak Republic. We will pay particular attention to SMEs operating in the field of tourism in individual regions, how they contribute or in the future can solve the problem of reducing regional disparities.
\end{abstract}

Keywords: Regional disparities, Regional development, Small and medium enterprises, Tourism.

\section{INTRODUCTION}

ignificant differences in the socio-economic level of regions, in their competitiveness, - the level of infrastructure is still a current problem in most countries of the European Union, including Slovakia. Differences in the development of individual regions in Slovakia have been evident since 1989. Disparities are generally understood as inequalities, differences, heterogeneities or differences. In the case of regional development, we understand disparity as different levels of social and economic development, which create inequalities between the individual units being compared. Matlovič, R., Klamár, R, Matlovičová, K. (2008, p.5) understand regional disparities as "differences in the degree of socio-economic development of regions which are the result of its unevenness." Gajdoš, P. (2008, p.102) states that "regional disparities are the product of the action of several factors, depending on the quality and development availability of potentials, but also the different positions from which individual regions entered the transformation process." Within the regional economy, there are various institutions and partnerships. Their mission and activities create conditions leading to the development of the region, the formation of its structure and the use of capacities. One of the ways to improve the economic performance of regions is to support the development of business activities and create a unique environment to unite companies of a similar nature.

Alexander Dubček University in Trenčín, Faculty of Social and Economic Relations, Študentská 3, 91150 Trenčín, Slovakia

2 Alexander Dubček University in Trenčín, Faculty of Social and Economic Relations, Študentská 3, 91150 Trenčín, Slovakia

3 Alexander Dubček University in Trenčín, Faculty of Social and Economic Relations, Študentská 3, 91150 Trenčín, Slovakia 
(Habánik et al, 2016, p.146). In the regions, it is important to use mainly local development potential. Small and medium-sized enterprises play an important role in regional development and are an integral part of any advanced market economy, given their contribution to the flexibility of the market mechanism, the potential of the competitive environment and innovative activities. The role of small and medium-sized enterprises in regional development is significantly influenced by the level and stability of the overall business environment. In this paper, we focus on small and medium-sized enterprises operating in the field of tourism in individual regions and their benefit to reducing regional disparities. In the analysis of regional disparities, we had to solve several methodological problems. Firstly, it was the selection of suitable territorial units - regions, secondly it was the selection of suitable indicators and the selection of appropriate statistical tools that allow comparison. In our research, we used the regions of the Slovak Republic (NUTS III level) and the division at the NUTS II level as suitable territorial units. When deciding on the selection of suitable indicators, we were limited by the limitations in the availability of suitable data. Many data are not systematically monitored and therefore a relevant analysis would not be possible. In the analysis of regional disparities, we included the following indicators: registered unemployment rate, regional gross domestic product per capita, motorway network in the regions, at-risk-of-poverty rate in the regions, number of facilities and beds in the regions. We monitored most of the indicators for the period 2010-2019. In some cases, we had to limit ourselves to the period 2010-2018. In the literature we can meet with the application of several statistical tools and indicators to measure disparities. The coefficient of variation is a relative measure of the dispersion derived from the standard deviation (ratio of standard deviation to mean). It is a more suitable tool for comparative analyzes, because it does not depend on the measured values of input indicators. Using the coefficient of variation, we can assess the size of regional differences in terms of selected parameters, but we can also compare these differences.

$$
V_{k}=\sqrt{\frac{\sum_{i=1}^{n}\left(x_{i}-\bar{x}\right)^{2}}{n}} \cdot \frac{1}{\frac{1}{n} \cdot \sum_{i=1}^{n} x_{i}}
$$

Where:

$V_{k}$ is the coefficient of variation

$n$ is the number of observed units,

$x_{i}$ is the value of the indicator $\mathrm{x}$ for the $\mathrm{i}$-th region,

$x$ is the average rate of the indicator in the whole higher order.

The Gini concentration coefficient was created as a tool for measuring pension inequality. It ranges from 0 (absolute equality) to 1 (absolute inequality). It can be calculated in several ways. This is twice the area between the ideal and real Lorenz curve.

$$
G I N I=\frac{2}{n-1} \sum_{i=1}^{n}\left|F_{i}-Q_{i}\right|
$$

Where:

GINI is the Gini concentration coefficient

$n$ is the number of observed units,
$F_{i}$ is$$
F_{i}=\frac{i}{n}
$$ 


\section{Development of regional disparities in the Slovak Republic based on selected socio- economic indicators}

The first of the indicators used in the analysis of regional disparities was the unemployment rate analyzed at the regional NUTS III level. This indicator is a suitable indicator for analyzing socio-economic development in individual regions. It is calculated as the ratio of the available registered number of unemployed to the number of economically active population, where the number of economically active population in the region is mainly affected by the deteriorating demographic situation in some regions of the Slovak Republic (aging of population, migration of the population for work to more developed regions or abroad). Based on the values given in table 1, we can state decreasing differences in the indicator of the registered unemployment rate between the regions of Slovakia in the analyzed period, which can confirm that the development of the economy in the period positively affected the unemployment rate in the regions. The Prešov region has the long-term highest unemployment rate, followed by the Košice region and the Banská Bystrica region.

Table 1. Registered unemployment rate in \%

\begin{tabular}{|c|c|c|c|c|c|c|c|c|c|c|}
\hline \multicolumn{11}{|c|}{ Registered unemployment rate (in\%) } \\
\hline region / year & 2010 & 2011 & 2012 & 2013 & 2014 & 2015 & 2016 & 2017 & 2018 & 2019 \\
\hline region of Bratislava & 4,63 & 5,41 & 5,72 & 6,17 & 6,13 & 5,34 & 4,51 & 3,05 & 2,62 & 2,83 \\
\hline region of Trnava & 8,17 & 8,88 & 9,43 & 9,16 & 8,03 & 6,71 & 4,41 & 2,6 & 2,31 & 2.63 \\
\hline region of Trenčín & 9,51 & 9,95 & 10,89 & 10,74 & 9,56 & 7,71 & 5,85 & 3,53 & 2,93 & 3,2 \\
\hline region of Nitra & 11,76 & 13,27 & 14,08 & 12,52 & 11,21 & 9,71 & 6,96 & 4,05 & 3,12 & 2,93 \\
\hline region of Žilina & 10,86 & 11,91 & 12,79 & 12,51 & 10,91 & 8,86 & 6,92 & 4,7 & 4,04 & 3,96 \\
\hline $\begin{array}{l}\text { region of Banská } \\
\text { Bystrica }\end{array}$ & 18,86 & 19,83 & 20,81 & 18,26 & 17,22 & 14,94 & 12,8 & 8,67 & 7,03 & 6,69 \\
\hline region of Prešov & 17,75 & 18,95 & 20,66 & 19,35 & 17,45 & 15,5 & 13,91 & 9,68 & 8,61 & 8,19 \\
\hline region of Košice & 16,78 & 18,76 & 19,58 & 17,23 & 15,92 & 14,39 & 12,76 & 9,94 & 8,17 & 7,57 \\
\hline coefficient of variation & 0,3847 & 0,3732 & 0,3697 & 0,3295 & 0,401 & 0,3596 & 0,4363 & 0,5033 & 0,5081 & 0,459 \\
\hline GINI coefficient & 0,24732 & 0,23918 & 0,23041 & 0,212034 & 0,20145 & 0,2138 & 0,26994 & 0,31093 & 0,312975 & 0,280676 \\
\hline
\end{tabular}

Source: Statistical Office of the Slovak Republic (2020), own calculations and processing

Regional gross domestic product per capita is a basic measure of a region's performance, so it is part of our analysis of regional disparities. From the data given in table 2 it is clear that in the whole monitored period there was an increase in regional gross product per capita in individual regions of the Slovak Republic as well as that the Bratislava Region has long been the most efficient region in Slovakia. The value of the indicator in absolute terms increased by EUR 7,740.22 in the Bratislava region in the observed period. The least efficient region has long been the Prešov region, followed by the Bansko Bystrický and Košice regions. Based on the development of the value of the coefficient of variation between all regions of the Slovak Republic at the NUTS III level, we cannot unequivocally state that differences in the amount of gross domestic product per capita between the regions of Slovakia in the analyzed period significantly decreasing. The indicator reached the lowest level in 2018. The development of the value of the GINI coefficient copies the development of the value of the coefficient of variation, so it is balanced in the long run. The indicator of the regional development index calculated by the EU also shows significant differences in the development of individual regions of the Slovak Republic at the NUTS II level, see table no.3.

The Regional Development Index points out that the Bratislava region has long been the most developed region in the Slovak Republic. Other regions of Slovakia achieve a medium level of regional development, but in the long run the lowest level is in the East Slovakia region (NUTS III level: Košice region and Prešov region) and is followed by the Central Slovakia region (NUTS III level: Banská Bystrica region and Žilina region). 
Table 2. Regional gross domestic product per capita in EUR

\begin{tabular}{|l|c|c|c|c|c|c|c|c|c|}
\hline \multicolumn{10}{|c|}{ Regional gross domestic product per capita in EUR } \\
\hline & $\mathbf{2 0 1 0}$ & $\mathbf{2 0 1 1}$ & $\mathbf{2 0 1 2}$ & $\mathbf{2 0 1 3}$ & $\mathbf{2 0 1 4}$ & $\mathbf{2 0 1 5}$ & $\mathbf{2 0 1 6}$ & $\mathbf{2 0 1 7}$ & $\mathbf{2 0 1 8}$ \\
\hline Region of Bratislava & 31095,78 & 32793,71 & 32862,47 & 34543,62 & 34460,69 & 36157,86 & 36657,33 & 37514,49 & 38836,00 \\
\hline Region of Trnava & 13863,69 & 14940,46 & 15187,10 & 15073,50 & 15777,52 & 15667,62 & 16191,49 & 16702,29 & 17917,48 \\
\hline Region of Trenčín & 10912,38 & 11706,48 & 12003,48 & 11699,84 & 12015,03 & 12553,47 & 12411,41 & 12511,77 & 13741,78 \\
\hline Region of Nitra & 10052,03 & 11134,63 & 12189,44 & 11804,78 & 12028,61 & 12200,01 & 12571,72 & 13293,20 & 13768,71 \\
\hline Region of Žilina & 11095,77 & 11769,53 & 11713,70 & 11717,77 & 12274,51 & 12890,59 & 12912,09 & 13305,64 & 14078,55 \\
\hline $\begin{array}{l}\text { Region of Banská } \\
\text { Bystrica }\end{array}$ & 9196,38 & 9586,50 & 9666,44 & 9847,08 & 99911,78 & 10578,30 & 10753,07 & 11292,08 & 12064,18 \\
\hline Region of Prešov & 7057,73 & 7360,17 & 8076,19 & 8016,83 & 8360,36 & 8807,11 & 9036,14 & 9308,20 & 10388,55 \\
\hline Region of Košice & 9969,20 & 10190,90 & 10649,70 & 10731,89 & 11112,08 & 11890,90 & 11729,72 & 12896,46 & 13352,95 \\
\hline coefficient of variation & 0,550492 & 0,547922 & 0,5249397 & 0,558649 & 0,538649 & 0,541243 & 0,5430694 & 0,530826 & 0,5113511 \\
\hline GINI coefficient & 0,270987 & 0,274163 & 0,26196 & 0,270835 & 0,265569 & 0,260588 & 0,260462 & 0,256005 & 0,2455731 \\
\hline
\end{tabular}

Source: Statistical Office of the Slovak Republic (2020), own calculations and processing

Table 3. European Regional competitiveness index

\begin{tabular}{|l|c|c|c|c|}
\hline region/year & $\mathbf{2 0 1 3}$ & $\mathbf{2 0 1 6}$ & $\mathbf{2 0 1 9}$ & Stage of development \\
\hline Bratislava Region & 0,378 & 0,276 & 0,43 & high \\
\hline Western Slovakia & $-0,562$ & $-0,579$ & $-0,38$ & medium \\
\hline Central Slovakia & $-0,749$ & $-0,69$ & $-0,53$ & medium \\
\hline Eastern Slovakia & $-0,871$ & $-0,846$ & $-0,72$ & medium \\
\hline
\end{tabular}

Source: https://ec.europa.eu/regional_policy/en/

By analyzing regional disparities, we find that there is a deepening of regional differences in the conditions of the Slovak Republic, which causes the formation of an imaginary dividing line of the southwest and northeast direction. What does it mean? This means the division of the territory of the Slovak Republic into regions with different attractiveness, with differentiated development dynamics, performance and thus also competitiveness. Persistent differences in the dynamics of regional development cause social and economic polarization of regions. They form marginal regions called regions of poverty, which lag significantly behind both socially and economically (table no. 4). The following table shows the percentage of the population at risk of poverty. Based on the development of the value of the coefficients of variation and the GINI coefficient, we can state that it increases the inequality between the regions of East and West Slovakia in terms of at-risk-of-population poverty, which is a consequence of increasing regional differences between these territories. As a result, the number of least developed regions in the Slovak Republic has increased to 20 districts (NUTS IV level region). These districts are concentrated in the Prešov region where there are at most 9 districts, in the Košice region there are 6 districts and in Banská Bystrica there are 5 districts. Up to one fifth of the Slovak population lives in the least developed regions of the Slovak Republic.

Table 4. At risk of poverty rate by NUTS 2 regions percentage of total population

\begin{tabular}{|l|r|r|r|r|r|r|r|r|r|}
\hline \multicolumn{8}{|c|}{ At-risk-of-poverty rate by NUTS 2 regions percentage of total population } \\
\hline region/year & $\mathbf{2 0 1 0}$ & $\mathbf{2 0 1 1}$ & $\mathbf{2 0 1 2}$ & $\mathbf{2 0 1 3}$ & $\mathbf{2 0 1 4}$ & $\mathbf{2 0 1 5}$ & $\mathbf{2 0 1 6}$ & $\mathbf{2 0 1 7}$ & $\mathbf{2 0 1 8}$ \\
\hline Bratislava Region & 5,1 & 7,2 & 6,3 & 8 & 7,8 & 7,3 & 5,4 & 4,6 & 4,3 \\
\hline Western Slovakia & 10,3 & 11,4 & 11,9 & 11,5 & 10,4 & 10,1 & 10,7 & 10 & 8,6 \\
\hline Central Slovakia & 13,1 & 13,1 & 14,1 & 13,3 & 15,3 & 14,9 & 14,7 & 14 & 15,2 \\
\hline Eastern Slovakia & 15,8 & 16,9 & 16,7 & 15,8 & 14,9 & 14,5 & 16,3 & 16,8 & 17,1 \\
\hline coefficient of variation & 0,3576 & 0,3257 & 0,3129 & 0,2338 & 0,2596 & 0,2703 & 0,3574 & 0,404 & 0,4537 \\
\hline GINI coefficient & 0,2626 & 0,2112 & 0,2272 & 0,1728 & 0,186 & 0,1937 & 0,2597 & 0,2981 & 0,3319 \\
\hline
\end{tabular}

Source: https://ec.europa.eu/eurostat/data/statistics-a-z/abc, own calculations and processing 
The reasons for the emergence of regional disparities in the conditions of the Slovak Republic can be summarized in the following points:

- low competitiveness of material production and services,

- differentiated educational structure,

- spatially differentiated concentration of foreign investments and capital as factors of region development,

- imbalances in regional labor markets,

- Insufficient quality and availability of public infrastructure,

- differentiated intensity of the absorption capacity of the business environment.

Factors of possible development of regions and reduction of regional disparities:

- efficient use of labor,

- better use and development of the region's production potential,

- increasing the innovation capacity of regions,

- increasing support for SMEs in the regions, especially in the field of tourism,

- improving the accessibility of regions by building infrastructure,

- improving the availability of public services.

Table 5. Number of SMEs doing business in tourism by size category (as at 30 June 2020)

\begin{tabular}{|l|r|r|}
\hline size category & number of active SMEs & \multicolumn{1}{|c|}{ share of active SMEs } \\
\hline micro-enterprises & 24514 & $96,46 \%$ \\
\hline small businesses & 828 & $3,26 \%$ \\
\hline medium-sized enterprises & 64 & $0,25 \%$ \\
\hline large companies & 7 & $0,03 \%$ \\
\hline total & 25413 & $100,00 \%$ \\
\hline
\end{tabular}

Source: The position of SMEs in tourism with regard to current developments in the industry, SBA, Bratislava, 2020, p. 17

The solution to regional disparities is the effective support and development of business activities in the field of tourism. Tourism activities are linked to the place of its origin, i.e. the region. Therefore, we can consider them as a driving force for the economic development of the region. Tourism is a dynamically developing service sector, which is often considered to be the only tool for the development of lagging regions while preserving the quality of the region's environment and protecting native cultures. Tourism in the Slovak Republic is significantly dominated by small and medium-sized enterprises headed by micro-enterprises (Table 5), because thanks to their flexibility they can flexibly satisfy specific and individual requirements on the demand side. Small and medium-sized enterprises, micro-enterprises create jobs in the regions, contribute to the growth of the region's performance, also have an impact on the growth of revenues to local budgets, etc.

Table 6. Headquarters of SMEs doing business in tourism

\begin{tabular}{|l|c|c|}
\hline & $\begin{array}{c}\text { Number of active SMEs as of } \\
\mathbf{3 0 . 6 . 2 0 2 0}\end{array}$ & $\begin{array}{c}\text { Share of active SMEs } \\
\text { as of 30.6.2020 }\end{array}$ \\
\hline Region of Bratislava & 5959 & $23,5 \%$ \\
\hline Region of Trnava & 2787 & $11,0 \%$ \\
\hline Region of Trenč́n & 2294 & $9,0 \%$ \\
\hline Region of Nitra & 2932 & $11,5 \%$ \\
\hline Region of Žilina & 2972 & $11,7 \%$ \\
\hline Region of Banská Bystrica & 2714 & $10,7 \%$ \\
\hline Region of Prešov & 3185 & $12,5 \%$ \\
\hline Region of Košice & 2563 & $10,1 \%$ \\
\hline
\end{tabular}

Source: The position of SMEs in tourism with regard to current developments in the industry, SBA, Bratislava, 2020, p. 19 
Regional development in the context of the given facts can therefore be perceived as a "byproduct" of tourism and vice versa. The development of tourism in the region brings investors who build or improve the local infrastructure, facilities of the region and provide tourists and locals with more opportunities and a better quality of life. However, it can work the other way around. Because tourism depends on local infrastructure. The quality of infrastructure is an essential determinant of the flow of tourists to the region and thus contributes to the overall development of the region and the reduction of regional disparities. Of course, tourism also brings with its negative effects Table 7.

Table 7. The impact of tourism on the development of the region

\begin{tabular}{|l|l|}
\hline Positive effects & Negative effects \\
\hline - Stops rural depopulation & $\begin{array}{l}\text { - It leads to a unilaterally oriented and } \\
\text { - Creates jobs }\end{array}$ \\
- Brings revenue & - If it develops in an uncoordinated manner, it \\
- Finances infrastructure construction & $\begin{array}{l}\text { - Occupies land by building facilities } \\
\text { - Improves living conditions }\end{array}$ \\
- Supports agriculture and improves care for & $\begin{array}{l}\text { - It burdens nature and the landscape } \\
\text { - the landscape }\end{array}$ \\
- Strengthens the feeling of belonging to the & $\begin{array}{l}\text { - Brings social tensions and increases } \\
\text { region }\end{array}$ \\
\hline
\end{tabular}

Source: Gregorová, B. Neradný M, Klaučo M., Masný M., Balková N. 2015. Cestovný ruch a regionálny rozvoj. UMB Banská Bystrica. p. 81

\section{CONCLUSION}

As stated by Grenčíková, A. et al $(2019$, p. 75$)$ : "the area of tourism is influenced by the unpredictability of climatic conditions and customer behavior, and then accommodation and catering services must be provided by support activities, which include e.g. opportunities for sports, hiking, wellness, the possibility of visiting historical monuments and other attractions. Animation services are also used and it is becoming more and more popular, for example. gastronomic tourism, or agrotourism as an escape from the hustle and bustle of the big city, active rest from the stressful factors of today's hectic times." And these facts create a large space for the development of a wide range of business activities of SMEs and the possibility of starting economic activities in lagging regions of the Slovak Republic. So, in conclusion, we can say that the right combination of economic policy instruments and effective regional policy will be able to gradually erase regional disparities in the longer term and contribute to economic growth, job creation and the efficient use of regional resources.

\section{REFERENCES}

Gajdoš, P. (2008) Current state and development of regional disparities in Slovakia (with emphasis on underdeveloped regions). In: Gajdoš, P., ed., Regional disparities in Central Europe. Sociologický ústav SAV, Bratislava, p. 98-115

Habánik, J., Kordoš, M., Hošták, P. (2016) Competitiveness of Slovak economy and regional development policies Journal of international studies, vol 9, pp.144-155

Matlovič, R., Klamár, R., Matlovičová, K. (2008) Vývoj regionáônych disparít začiatkom 21. Storočia na Slovensku vo svelte vybraných indikátorov. Regionální studia / Czech Regional Studies, recenzovaný vedecký časopis, 02/2008, ISSN 1803-1471, p. 2-12

GÚČIK, M. (2010): Cestovný ruch. 1. vyd. Banská Bystrica: DALI-BB, 2010, 307 p. ISBN 978-80-89090-80-8 
GÚČIK, M. a kol. (2012). Manažment ciel’ového miesta cestovného ruchu. 1. vyd. Banská Bystrica: Slovak-Swiss Tourism, DALI BB, 2012, 219 p. ISBN 978-80-8141-025-3

Gregorová, B. Neradný M, Klaučo M., Masný M., Balková N. (2015): Cestovný ruch a regionálny rozvoj. UMB Banská Bystrica

Grenčíkova, A., Petrušová, D., Sokol J.(2019), The impact of Industry 4.0 on tourism services online: https://fsev.tnuni.sk/konferencia2018/Zbornik-industry-4-0.pdf.

In: The impact of Industry 4.0 on job creation Zborník odborných príspevkov $\mathrm{z}$ medzinárodnej vedeckej konferencie. - Trenčín: TnUAD, 2019. - ISBN 978-80-8075837-0. - p.74-80.

https://www.iz.sk/sk/projekty/inkluzivny-rast/najmenej-rozvinute-okresy

The position of SMEs in tourism with regard to current developments in the industry, SBA, Bratislava, 2020, online: http://monitoringmsp.sk/wpcontent/uploads/2020/10/Postavenie-MSP-v-cestovnom-ruchu_final.pdf

https://ec.europa.eu/eurostat/data/statistics-a-z/abc,

Statistical Office of the Slovak Republic, http://datacube.statistics.sk/\#!/lang/sk

Statistical Office of the Slovak Republic, http://statdat.statistics.sk/cognosext/cgibin/cognos.cgi?b_action=xts.run\&m=portal/cc.xts\&gohome= 